\title{
Human Basophil Phenotypes and the Associated Signaling Mechanisms
}

\author{
Donald MacGlashan, Jr.*
}

Johns Hopkins Asthma and Allergy Center, 5501 Hopkins Bayview Circle, Baltimore, MD 21224, USA

\begin{abstract}
A variety of studies have shown that human basophils are participants in allergic reactions and a recent study has indicated that it may even be important in the immediate reaction generally associated with a mast cell response. Therefore, it is important to understand how the function of these cells is regulated and whether the functionality has a relationship to the presence and severity of diseases like atopy. There are many indications that for IgE-mediated secretion, the regulation of syk expression is relevant to the broad distribution of outcomes observed in the general population. The factors influencing the expression of syk will be explored. In addition the outcomes of studies surveying signal element expression by various methods will be discussed.
\end{abstract}

Key Words: Signal transduction, syk, SHIP, FceRI, CD34-progenitors.

\section{INTRODUCTION}

In humans, basophils and mast cells are believed to participate in allergic reactions. Most of the evidence for their participation is circumstantial as it is not yet possible to selectively eliminate both of these cells types and ask whether an IgE-mediated response is blunted. However, both cell types bear the high affinity $\operatorname{IgE}$ receptor and express internal granules that can be induced by aggregation of cell surface bound $\operatorname{IgE}$ to release histamine and both cell types can be observed in tissue sections and can appear degranulated. One missing piece of information is the relative contribution of the two cells types to an immediate hypersensitivity reaction but a starting point for considering this question is the relative presence of the two cell types and it is here that the answers already become nuanced. The evidence suggests that tissue bound mast cells survive for several months [1-4] while basophils circulate for only 12 hours $[5,6]$. If the bone marrow generated an equal number of basophil and mast cell precursors per hour, the difference in lifetimes would predict $100-150$ fold more mast cells in the body. This prediction is likely true; with tissue studies suggesting 0.2-0.5 million mast cells per gram, a $70 \mathrm{~kg}$ man would have 14-35 billion mast cells. With 20,000-50,000 basophils per $\mathrm{ml}$ of blood, there would be 100-250 million basophils in circulation, or ca. 1/100 the number of mast cells. This simple calculation suggests that the bone marrow makes approximately equal numbers of both cell types per unit of time. There are several potentially important caveats. First, basophils in the bone marrow and tissue are not considered in the calculation. Second, basophils in circulation are already mature while mast cells mature in the tissue of their residence. Trafficking studies suggest that the mature circulating basophil is a rapidly mobilized mature cell that can enter and concentrate in tissue sites very rapidly [7-9]. While an equal number of mast cell precursors may be able to be recruited to the same tissue

*Address correspondence to this author at the Johns Hopkins Asthma and Allergy Center, 5501 Hopkins Bayview Circle, Baltimore, MD 21224; Tel: 410-550-2145; Fax: 410-550-2130; E-mail: dmacglas@jhmi.edu sites, they are presumably not yet mature and would require some time before reaching maturity. It is this attribute of basophils that adds an interesting dynamic to all allergic inflammatory reactions.

A second feature of studying the basophil is its accessibility. While it would be useful to study both mast cells and basophils in patients, removing large pieces of tissue from any site is not possible except under duress. If one is interested in exploring the relationship between IgE-bearing, histamine-containing cells and clinical allergy, then the basophil is the cell of choice. This review will take the approach that basophils are both important to allergic reactions and present evidence supporting this view and also consider that basophils provide a window on the allergic condition. The viewpoint presented does not consider the newly developing field of basophil biology that implicates the basophil in modulation of the primary and secondary immune responses as these are topics that are relevant, for the moment, to the mouse and covered extensively in other reports.

\section{BASOPHILS IN ALLERGIC REACTIONS}

Some of the first observations that placed the basophil squarely in the middle of an allergic reaction came from the early experimental allergen challenges in humans. By instilling antigens into the nose, it became possible to monitor both mediators and cells in the resulting fluids that characterized an allergic nasal response. Washing the nasal cavities with saline recovered both mediators and cells. Once the reaction was monitored for longer than the first few minutes of the reaction it became clear that the reaction changed in time. Within minutes of antigen exposure, histamine and prostaglandin D2 were apparent in the nasal lavage fluids [10-15]. Minimal numbers of cells other than epithelial cells were apparent. In vitro studies had, at the time of these first experiments, only recently noted that airway mast cells secreted both histamine and PGD2 while peripheral blood basophils did not secrete prostaglandins. Therefore, it could be concluded that either 1) mast cells alone or 2) both mast cells and basophils contributed to the initial reaction. However, at 
times later than 8 hours, and following a lull in measurable mediator production, the histamine content of the nasal lavage fluids increased a second time. But in this case, there was no PGD2. This pattern was consistent with the secretory profile of basophils and led to the hypothesis that basophils were the primary histamine-secreting participant of the socalled late phase reaction. There always remained the possibility that the stimulus during this late phase reaction was not antigen but a secretagogue that induced histamine release from mast cells but not PGD2 release. But based on in vitro studies, this particular profile of mediator secretion has not been found for human mast cells. When the cellular constituents of the nasal lavage fluids were eventually examined, it was apparent that there was a relatively selective recruitment of eosinophils and basophils into the reaction. It required some careful comparative techniques to be sure that the histamine-containing cell being observed was indeed the basophil but by a variety of criteria, the cell most closely resembled a basophil [14, 15]. At the time these initial studies were done, a selective marker of basophils had not been identified. Today, there are at least two antibodies [16, 17] that selectively identify basophils distinctly from mast cells. Studies in other tissues, notably the skin $[7,8,18]$, had also begun to identify a late-phase reactant cell as the basophil and when the antibodies that had been developed to selectively stain basophils were employed, the supposition was validated, basophils migrated into these late reactions.

In a study that has only recently been published [19], a different approach to exploring the role of basophils in allergic reactions was employed. The new anti-allergy therapeutic, omalizumab, had been observed to decrease the expression of FceRI on circulating basophils and tissue mast cells [20]. However, there was a considerable difference in the timing of these reductions in the two cell types, at least as observed in circulating basophils and skin tissue mast cells. Within the first week of omalizumab (monoclonal nonaggregating anti- $\operatorname{IgE}$ antibody) treatment, expression of FceRI on peripheral blood basophils had decreased 90-95\% and cell surface IgE had decreased to a somewhat greater extent. But FceRI expression on skin mast cell biopsy samples had not decreased to a measurable extent (although the technique was relatively crude for tissue samples). The rate of decrease on mast cells was actually the predicted rate based on in vitro studies done both before and after these initial observations $[21,22]$. Therefore, the rate of decrease in the basophils was surprisingly fast. There is now reasonable evidence supporting an explanation for this observation that will not be covered in detail here [23, 24]. This evidence supports a view that the change in peripheral blood basophils reflects the rapid rate of replacement of these cells and the slow rate in the skin reflects both the slow rate of mast cell replacement and the intrinsic long $\left(\mathrm{T}_{1 / 2}=10\right.$ days $)$ dissociation of IgE from FceRI [21, 22]. There was also a practical consequence; the peripheral blood basophil would be predicted to lose its functional response to antigen much faster than the mast cell. This provided a window of time during which patients being treated with omalizumab would, theoretically, respond to antigen only through their mast cells; the basophil would be functionally removed from the reaction. The results of this initial study were somewhat surpris- ing. After starting a patient on omalizumab, the specific antigen-driven response of basophils was monitored weekly and when it fell to less than $20 \%$ of its initial response, the nose of the patients was challenged with antigen and symptoms and PGD2 release monitored. At this point, which occurred between 14 and 45 days, it was found that PGD2 in nasal lavage fluids was unaffected, as predicted (i.e., the mast cell remained responsive). But clinical signs and symptoms were decreased by approximately $50 \%$ (compared to no change in placebo-treated controls). These results suggest that even the immediate nasal response was being partially mediated by basophils (or more properly, being mediated by a process that mirrored in time the decreased responsiveness of peripheral blood basophils).

These various clinical studies have provided substantial support for the view that the effector role for basophils is significant in immediate allergic reactions. Since the basophil is relatively accessible, it becomes useful as a bio-sensor of the in vivo environment that regulates the allergic diathesis. The remainder of this review will focus on studies which explore this "bio-sensor", i.e., whether there are characteristics of basophils that have a connection with clinical outcomes or in more modern parlance, whether there are signature phenotypes of basophils correlated with allergic disease states.

\section{BASOPHIL PHENOTYPES}

The notion of granulocyte plasticity or phenotype related to allergic diseases was first found in studies of eosinophils. During the isopycnic separation of eosinophils it was noticed that a sub-population of eosinophils were hypodense, i.e., they floated on gradients where eosinophils normally pelleted $[25,26]$. The proportion of eosinophils that behaved with this characteristic was considerably greater in patients with marked allergic disease (severe rhinitis or more likely allergy with asthma). Subsequent studies have provided some support for the hypothesis that this condition results from exposure of circulating eosinophils to cytokines or stimuli $[27,28]$. There have been some indications that basophils experience a change in specific density in some subjects [29] but the relationship to disease is not well explored or very clear. In contrast, a well recognized, but thus far unexplained, characteristic of some subjects' basophils is enhanced spontaneous histamine release after isolating the cells from blood [30-33]. There remains considerable debate about the behavior of the cells in vivo because current data suggest that the spontaneous release only occurs when the cells are removed from the blood itself. Precise measurement of the histamine content per basophil is difficult, but no one has clearly detected a circulating basophil that is depleted of histamine content. The phenotype of the basophil appears to be sensitive to isolation and establishes a state whereby exposure to simple calcium-containing buffers allows some histamine release. The amount of spontaneous release one observes from an individual's isolated basophils has a relationship to the disease status. Spontaneous release is associated with food allergies in adults and children and there is a graded degree of spontaneous release that correlates with some metrics of asthma+allergy severity [30-34]. The mechanisms underlying the spontaneous release remain un- 
known but there is now considerably better understanding of the some of the regulatory signaling in basophils and this will be discussed below.

Histamine release is certainly the most studied attribute of human basophils. This is the first mediator to be identified with basophils and although the technology for its measurements takes many forms, some of which are cumbersome, it has now been studied for decades. But there are now many possible outcomes to examine and the field is slowly expanding into the use of these alternative outcomes to examine the hypotheses revolving around basophil phenotypes or signatures. Several examples include 1) arachidonic acid metabolism, which in the human basophil is most likely solely represented by the production of LTC4 [35-37]; 2) cytokines (e.g. IL-4, IL-13, IL-3) [38-41], chemokines (e.g., MIP1 $\alpha$ ) [42] and growth factor release (e.g., VEGF) [43] which are slow reactions that do not need to strictly correlate with histamine release; 3 ) activation markers, proteins that are expressed on basophils under various forms of stimulation; 4) adhesion of basophils to various substrates including endothelial cells [44]; and 5) changes in signaling species and granule contents [45]. Under the category of activation markers, there are at least six currently identified, CD63, CD203c, CD107a, CD107b, CD163 and CD13 [46-56]. CD63 is one of the earliest studied and has the most detailed history thus far. It is particularly interesting because there is evidence that CD63 is a histamine granule membrane protein so that its appearance on the basophil surface was initially thought to be a surrogate metric of degranulation or histamine release [57-59]. However, expression of CD63 is not synonymous with histamine release. Recently published studies from this laboratory [60] have proposed a possible explanation for the discordance that relies on the extensive observations that histamine release in human basophils follows two distinct pathways [61-65]. The form that allows granule fusion to the plasma membrane, so-called anaphylactic degranulation (AND), would likely allow CD63 expression since the membranes of the two compartments fuse and this does seem to be the case. The second method involves the shuttle of small vesicles between the granule and the plasma membrane, so-called piecemeal degranulation (PMD). These vesicles have been shown to contain histamine. It is postulated that they do not, however, shuttle CD63. There is some evidence to support this claim and there is evidence for two mechanisms to regulate which pathway is used. So, the discordance between CD63 expression and histamine release may occur because different conditions favor one of two possible pathways to get histamine out of the cell and increased CD63 only occurs with one pathway (AND).

The second most studied marker is CD203c and is interesting because its expression is largely limited to mast cells and basophils. But this marker can be clearly dissociated from degranulation and it is proposed to occupy a different compartment in cells, a compartment that is rapidly mobilized during various types of stimulation, including stimulation with IL-3 and phorbol esters.

Among the many efforts to find basophil phenotypes that associate with disease, the primary focus has been on stimulated release and for stimulation, the primary method has been through the $\mathrm{IgE}$ receptor because of its relevance to atopic diseases. But it is probably important to consider the many other methods of stimulating basophils especially if the phenomenon of spontaneous release is to be understood. There are a variety of innate receptors, such as FMLP and C5a, that are very active on basophils and several less wellstudied receptors that can also induce mediator secretion [66]. Not all secretagogues induce secretion of all types of mediators, so the profile of mediator release might be a way to query the type of stimulation the basophil experienced. This approach is complicated by the fact that cytokines also induce a wide variety of changes (see below) some of which appear to result in mediator release, but also which modify the profile of mediators released. A well-studied case is the effect of IL-3 on C5a-induced secretion [67-71]. In the type of basophil typically isolated from the peripheral blood of non-atopic subjects, C5a does not induce either LTC4 or IL4 secretion. However, pre-incubation with IL-3 acutely increases the C5a-mediated secretion of LTC4 and longer treatments with IL-3 allow C5a-mediated IL-4 secretion.

The "signature" that has been explored by several groups is the relationship of $\mathrm{IgE}$-mediated stimulation with atopic diseases. This is a complicated area because there are 1) technical differences in how IgE-mediated stimulation is done, 2) differences in the processing of cells, 3) differences in the nature of the stimulus and stimulation conditions, to name a few issues. So, there are mixed conclusions in the literature. Several studies have found differences in the ability of pan-IgE stimuli, like anti-IgE antibody, to induce histamine release from basophils of atopic patients vs. nonatopic patients and particularly, differences between nonatopic subjects and patients with asthma and allergies [7276]. But the differences are sometimes not very marked and do not seem to offer a clear explanation for the causal link between the function of a histamine-containing, IgE-bearing cell and disease. It goes without saying that the association could be a result of or the cause of atopic disease. In profiling the general population for IgE-mediated histamine release, it is noted that the statistical mode of the distribution is somewhat less than $50 \%$ histamine release, i.e., in general, the cell is tuned to not secrete everything even under conditions of maximal stimulation. But there lie some subpopulations within the generally Gaussian-like population distribution. Most notable are the basophils that don't secrete in response to anti-IgE antibody, the so-called non-releasers [77]. These basophils do secrete to non-IgE-dependent stimuli, so the non-releaser condition is selective for IgE-mediated stimulation. However, it is not strictly selective for FceRI because it has recently been found that stimulation through the LILRA-2 receptor is tightly associated with the functional outcome for FceRI-mediated stimulation [78]. A variety of studies lead to the conclusion that there is an intrinsic deficiency in these cells that bears some exploration. This will be covered in detail below as it forms the basis for rethinking the nature of the basophil phenotype. However, it is also worth noting that the validity of the association or the precise influence of the basophil on the severity of a patient's atopic disease is not the only interesting aspect of this set of observations. The breadth of the response in the general population raises questions about how it comes about because understanding the genesis of the distribution may 
provide insights into the natural and pathological states in vivo.

There are two additional phenotypes that have been noted in patients with atopic diseases. The first of these may have a relationship with the spontaneous release behavior. When nasal lavage fluids were first being obtained, they were tested for their ability to induce secretion from basophils. It was noted that they contained a substance that would induce histamine release that was IgE-dependent [79]. While there are also chemokines in these lavage fluids that can induce secretion $[80,81]$, the substance that was ultimately isolated was a unique factor, a protein with some cytokine-like characteristics, that was simply called histamine-releasing factor. The protein has been cloned [82] and the cloned protein retains the interesting characteristic of being dependent on the presence of IgE on the basophil surface. However, only certain IgE antibodies allow the basophil to respond to this factor [79] which has been identified as TCTP (translationally controlled tumor protein), a protein that also has an intracellular role. There is no evidence that it binds to $\mathrm{IgE}$ directly (e.g., it is not an antigen) [83]. The association with disease is two fold. First, the type of IgE that can confer to a sensitized basophil the ability to respond to HRF only comes from certain kinds of patients. Notably, children with food allergies have the correct type of $\operatorname{IgE}$ [33]. The nature of the $\operatorname{IgE}$ that allows this biological behavior is still unknown [84, 85]. In addition, HRF induces secretion from basophils of these patients only during the active phase of their disease. A food-elimination diet that induces a reduction in the patient's disease also reduces the responsiveness of the patient's basophils to HRF. Patients with more severe forms of allergic disease also generate the correct type of $\mathrm{IgE}$ and have basophils that are sensitive to HRF.

The second instance of a non-normal basophil phenotype is found in patients with chronic idiopathic urticaria (CIU) $[86,87]$. Approximately $50 \%$ of patients have basophils that are nearly unresponsive to IgE-mediated stimulation. This phenotype is reversed when the patients' urticaria is in remission. There is an extensive history to the study of basophils in patients with urticaria and one popular hypothesis is that some of these patients have circulating antibodies specific for either IgE or FceRI [88-94]. While this would seem a discovery with strong explanatory power, it has become clear that this is a situation that is common in many individuals [94, 95]. Some studies have noted that non-atopic subjects have levels of these antibodies equivalent in frequency and quantity similar to patients with CIU. Therefore, more recent studies have turned to a search for a change in the basophil's intrinsic secretory machinery for an explanation of the blunted secretory phenotype (although not necessarily a cause of the disease).

\section{SECRETORY MECHANISMS}

To properly understand the basis for basophil phenotypes, as they relate to any type of stimulation, it is necessary to know about the signaling mechanisms that lead to secretion or other activation endpoints. This area of study is largely pioneered by work in non-human cells and lagging greatly behind these efforts are studies of human basophils due to their limited availability. As the story has evolved, the similarities between non-human basophil models (RBL cells, bone-marrow-derived mast cells, cell lines or rat peritoneal mast cells) are, of course, marked. But there are important differences as well; those that may relate more to the differences between mast cells and basophils and those that relate to species differences. The canonical framework for both FceRI-mediated and heterotrimeric receptors like FMLP are similar. For FceRI, the receptor must be aggregated, or at a minimum, its proximity to other FceRI receptors established by various means. As an immunoreceptor, the aggregation induces the association of various early tyrosine kinases that both phosphorylate the receptor to induce the formation of a reaction complex and phosphorylate reaction complex proteins. The src-family kinases and the ZAP70-family kinase, syk, form the early reaction. It is the involvement of syk that will form the basis for the majority of the remaining discussion.

Syk is an immuno-receptor tyrosine kinase in every type of white blood cell, although there are cells like the $\mathrm{T}$ cell where the other family member, ZAP-70, is critical in a subset of T cells, the $\alpha \beta$ T cells [96]. A variety of studies, using non-human and human models (basophils and mast cells) have shown that IgE-mediated functions are entirely dependent on the presence of a functional syk [97-99]. For human basophils, there is a very interesting metric whose precise significance is not entirely clear. Basophils express a median of $110,000 \mathrm{FccRI} / \mathrm{cell}$ in the general population and around $150,000 /$ cell in the atopic population (reflecting the somewhat higher level of IgE in the atopic population). But basophils only express approximately 25,000 syk molecules per cell [100]. This leads to a ratio of $1: 5$ to $1: 6$ for syk/FceRI, i.e., at least from the perspective of a pan-stimulus like anti$\mathrm{IgE}$ antibody, syk is expressed in rate-limiting amounts. With the exception of $\alpha \beta \mathrm{T}$ cell (where syk is possibly not present even at an extremely low level), the basophil is unique in this expression level, all other leukocytes express 5-30 fold more syk per cell (Fig. 1) [100]. Given the importance of syk in the functionality of FceRI, this differential expression pattern is interesting for its implications. In a survey of 20 signaling elements that are known to participate in the early steps of IgE-mediated signaling, the only element whose expression levels were as broad as IgE-mediated histamine release in the general population was syk (Fig. 2) [100]. Furthermore, the level of syk expression was well correlated to the magnitude of histamine release induced by anti-IgE antibody. Taken together with the low expression levels, relative to other leukocytes, it is tempting to speculate that the expression of syk is "tuned" to provide a level of function that lies near the threshold for responsiveness. This threshold is revealed by stimulation with a pan-stimulus like anti-IgE $\mathrm{Ab}$ but in a typical patient, only $1 \%$ of the $\operatorname{IgE}$ is specific for a given antigenic epitope. Therefore, it is less clear how its limited expression alters the antigenic response where there may be 1500 antigen-specific IgE per cell and 25,000 syk molecules. It is known that the maximum amount of histamine release that can be achieved with antigen is not substantially better than that achieved with anti-IgE Ab [100, $101]$; i.e., in terms of absolute release, the global ratio of syk to FceRI appears relevant. It is not clear why this would be true but one possibility is that at resting levels, there is some association between syk and non-aggregated receptors that effectively acts a "sink", creating an additional limitation on 


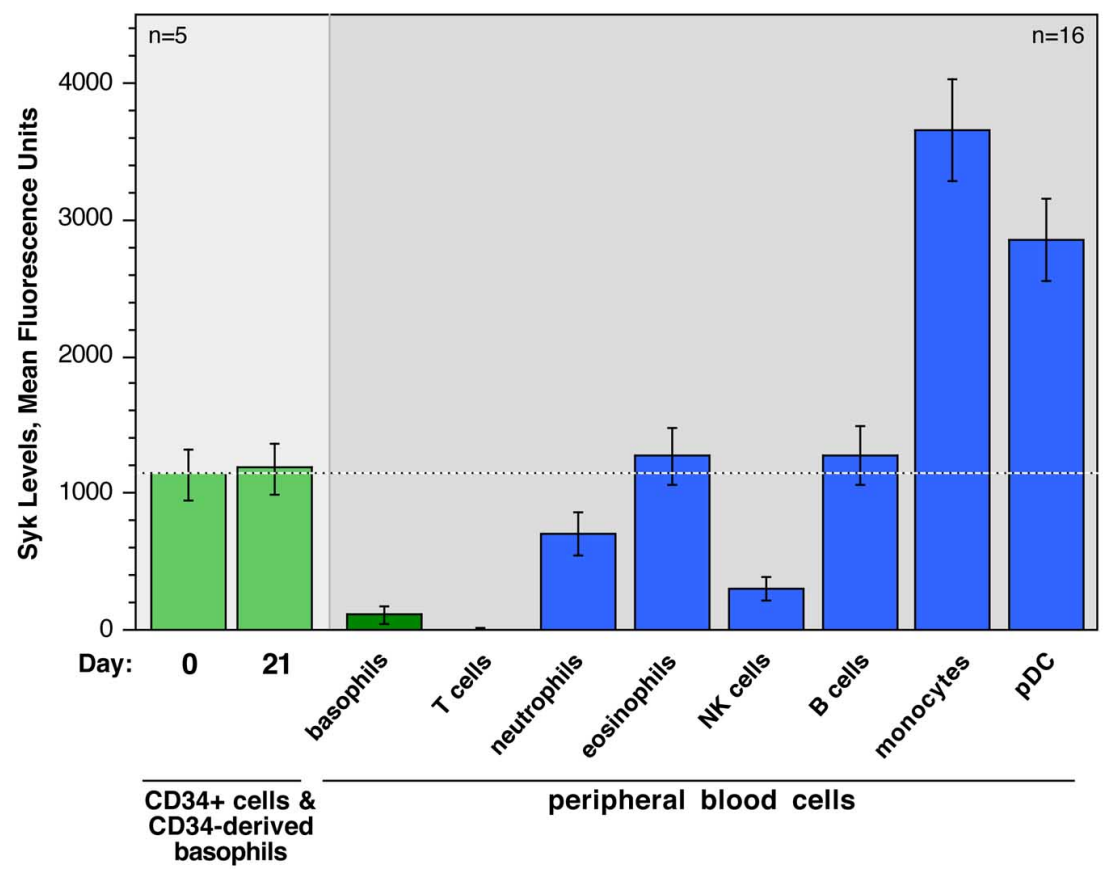

Fig. (1). Syk expression in leukocytes, including CD34+ progenitors and 3 week CD34-derived basophils.
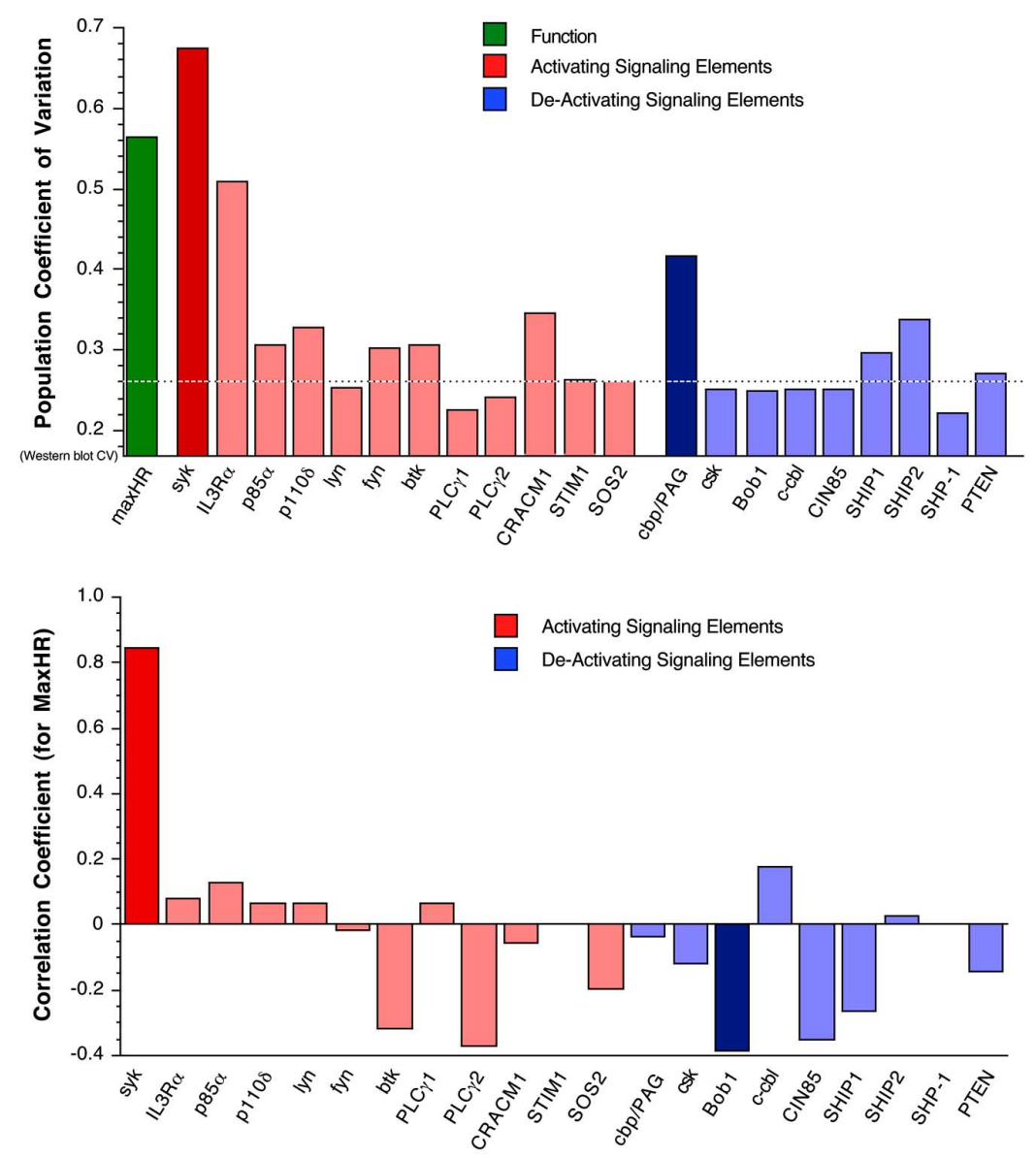

Fig. (2). Population variability in syk expression in human basophils. Top panel: coefficient of variation from a study of 28-35 subjects basophils (ca. 20\% atopic). Included in the plot is the CV for the optimal IgE-mediated release (maxHR). The dotted line is the expected CV for the methodology used to assess each signaling elements' expression. Bottom panel: correlation coefficient between the expression of a signaling element and maximum histamine release (maxHR). In this study, a statistical analysis placed the confidence limits for $\mathrm{p}<0.05$ significance between -0.451 to 0.295 . Therefore, only the positive correlation for syk and the negative correlation for BOB 1 were significant. 
the availability of syk during an antigen-driven aggregation reaction. It is also known that the expression level of syk also tunes the sensitivity of the basophil, i.e., the density of specific-IgE required for a half-maximal response [100, 101]. While the statistical association is not as strong as the relationship to the magnitude of the response, in this context, the level of syk expression does appear to regulate the ability of antigen to induce a response. If the statistical relationship between syk expression and the maximum IgE-mediated histamine release is relevant, then the statistical association between maximum histamine release and atopy or atopy with asthma suggests that expression of syk is associated with atopy. The question now being addressed is whether syk expression is a result of the in vivo conditions or a cause of potentially heightened pathological responses. The answer to this question begins with what is known about the regulation of syk expression.

\section{REGULATION OF SYK EXPRESSION}

Despite the critical role that syk appears to play in many immuno-receptor-mediated reactions, there is very little that is understood about its regulation. For example, regulation at the level of gene transcription has not been extensively studied. There are ca. 700 SNPs identified with the syk gene (using the gene boundaries defined in Genebank) but no associations with disease have been explored. No specific transcription factors have been identified although recent studies of tumor cell progression have noted an association with syk expression and silencing of the gene [102, 103]. Complete silencing represents an extreme form of regulation that is probably not relevant to the graded expression levels being considered (although possibly relevant to silencing in $\alpha \beta \mathrm{T}$ cells). In the study of human basophils, the issue can be split into three areas that have received some attention, 1) transcriptional control, 2) post-translational processing and 3) translational control.

As part of the recent survey of signal element expression in basophils it was noted that there was a modest distribution in syk mRNA among subjects' basophils that showed a modest correlation with syk protein expression levels [104]. This would imply some control of syk protein levels by a process that regulated syk mRNA levels, either through transcriptional regulation or changes in mRNA stability. It has also been noted that the mRNA for syk is under relatively dynamic control because treatment with actinomycin D results in its decay at a rate that is as fast as the decay in IL-4 mRNA observed after its induction following stimulation [96]. The implication is that syk mRNA is a relatively unstable species and its steady state presence in mature peripheral blood basophils requires continued transcriptional activity. These survey study results also suggest that these levels of syk mRNA have contributed to the expression of the protein. But this association is limited because there are also indications that despite the presence of significant levels of syk mRNA in peripheral blood basophils, little syk protein is being synthesized. The underlying issue is whether a mature peripheral blood basophils synthesizes proteins at rates that are similar to their immature bone marrow counterparts, i.e., during the final step in maturation, is there a global change in protein synthesis or are there specific changes in some proteins? This issue will be considered in the discussion on post-translational control.

The levels of syk mRNA can be manipulated in vitro. For basophils, IL-3 is a primary regulator of development and function. For reasons not yet understood, IL-3R is expressed on basophils at densities that markedly exceed the densities of cytokine receptors typically observed on cells. IL-3 is thought to be required for adequate basophil development although studies in mice suggest that basophil development occurs without IL-3 [105-108]. But, IL-3 does alter the frequency of progenitor development into basophils. Whether IL-3 modulates development in humans in the same way is not known. But many studies have demonstrated the significant effects of IL-3 on the behavior of mature peripheral blood basophils. The effects are global, cell survival increases and the basophil's responsiveness to all known stimuli is enhanced. This enhancement occurs on 3 time scales. The earliest time scale, minutes, results from some rapid signaling modifications such as activation of the MAPK pathways and the cross-over effects these changes have on other forms of stimulation $[67,109]$. The remaining two time scales required 12-24 hours or several days and depend on transcription [67]. In this context, IL-3 has been shown to increase the levels of syk mRNA [110]. It has not been determined if transcriptional rates of the syk gene are enhanced (actinomycin D suppresses all the late IL-3 functions [67] but inhibition of the early transcriptional events might be sufficient to disallow later changes that result in syk mRNA increases). In parallel, levels of syk protein are increased $[100,110]$. The change in syk expression is not unique, however. A variety of signaling species relevant to IgEmediated signaling are also increased following multi-day incubations in IL-3. Several that are increased to a greater extent than syk are also known to suppress signaling and one that has been noted to increase, c-cbl, is thought to directly down-regulate syk expression through its ubiquinylation activities [111].

In the context of human basophils, post-translational control of syk has received the most attention. Activation of the IgE-receptor results in multiple down-regulatory behaviors that serve to limit secretion. One of these down-regulatory processes results in the down-regulation of syk expression. Although not demonstrated with direct experiments in human basophils, it seems likely that the mechanism involves the association of the $\mathrm{c}$-cbl with the early reaction complex [111]. As an E3-ligase, c-cbl mediates the ubiquinylation of its target proteins. In this situation, syk in ubiquinylated multiple times and eventually lost to proteasomal degradation [112-114]. A property of this process that has implications for the regulation of syk is that it occurs at levels of stimulation that do not result in mediator release $[111,115]$. The process appears integrative since long periods of low level stimulation result in progressive loss of syk. It is also interesting that syk need not be active, although it does need to be recruited to the complex, for down-regulation to occur [116]. The evidence favors the view that c-cbl is recruited by phosphorylation steps that are dependent on src-family kinases, not syk itself and once recruited, c-cbl is able to mediate ubiquinylation of syk even though syk itself is not enzymatically active [99]. This process of syk down-regulation is highly variable among individuals [78] and the reasons for 


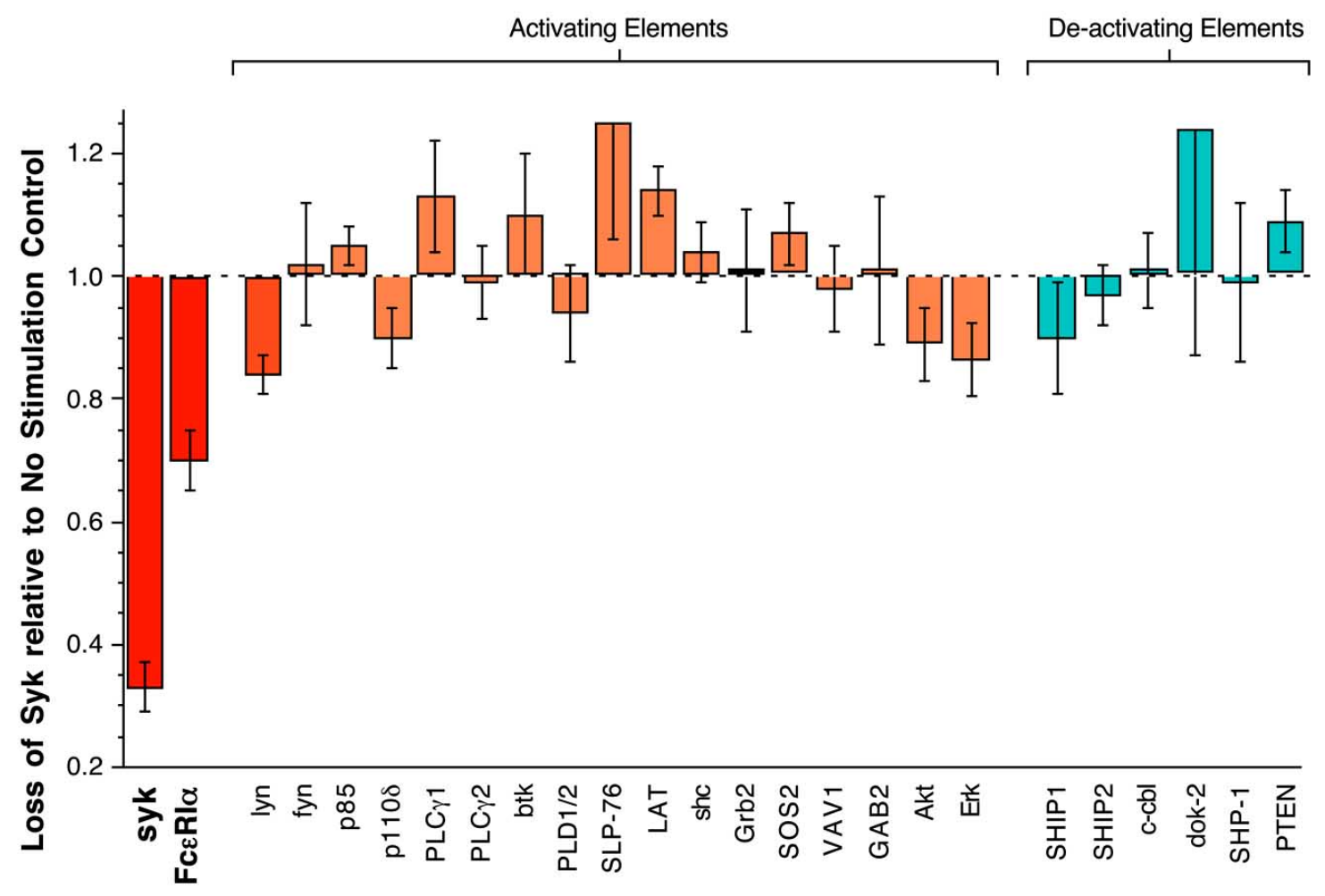

Fig. (3). Changes in signal element expression following 18 hours of IgE-mediated stimulation. The value of 1.0 represents the level of expression in un-stimulated basophils.

the differences are not yet understood. In addition, other stimuli that use syk as an early signaling kinase also induce loss of syk, although the loss doesn't appear to be as robust [78]. There is also evidence that a receptor, FMLP-R, that does not use syk for signaling can mediate a very modest loss of syk, possibly because FMLP also induces some c-cbl phosphorylation. Although there are individuals whose FceRI-activated basophils don't down-regulate syk very well, the majority of basophil preparations show $>75 \%$ down-regulation with activation. Fig. (3) shows that of 25 signaling elements surveyed only syk is lost upon IgEmediated stimulation to a significant degree. Therefore, this mechanism provides one significant way that syk expression may be selectively regulated.

Before, making note of possible translational control mechanisms, it is useful to discuss the implications of posttranslational mechanisms. The integrative nature of syk down-regulation with sub-optimal stimulation suggested the next series of experiments. First, it was noted above that syk expression in other leukocytes is generally much greater than its expression in basophils, 10 fold greater on average. This condition applies to CD34 progenitors and the basophils that can be derived from CD34 progenitors. Incubation of CD34 progenitors with IL-3 for 2-3 weeks results in cells that are phenotypically similar to basophils [96, 117, 118]. The resulting cell is not always a "perfect" basophil but it does have many properties that are associated with mature peripheral blood basophils, notably, expression of FceRI, FMLP-R, IL-3R, histamine-containing granules (1.3 pg/cell), alcianblue positivity, expression of CD203c and significant IgEand FMLP-mediated histamine release. Morphologically, a significant percentage of the cells have bi-lobed nucleus but there are also many cells that are large and not morphologically similar to mature basophils. In addition, on average, these cells express 11-fold more syk than a mature basophil. The expression level of syk in CD34 progenitors is similar to neutrophils and eosinophils, implying that to derive a neutrophil or eosinophil, no change in syk expression is necessary (see Fig. 1). To generate B cells or NK cells from a CD34 progenitor, only modest decreases are necessary and to become monocytes or dendritic cells, syk must be modestly up-regulated. But to become a basophil, syk must be markedly down-regulated. But if even the CD34-derived basophils show levels similar to neutrophils and eosinophils, it is not known whether this implies that under normal conditions, that this is the preferred state of expression in mature basophils. It may simply be a flaw in the method used to generate basophils in culture. Nevertheless, under the assumption that this was a natural state, the cells were chronically stimulated during development and the cells examined for phenotypic changes. A priori, it is not clear what would happen because the stimulus would be present even as the CD34 cell began to express FceRI; would the signaling machinery be present or similar in behavior at these earliest steps in maturation? The hallmark similarities between basophils from different subjects is the general similarity in histamine content, alcian blue staining and expression of FceRI (normalized for the different IgE levels in serum). When CD34 progenitors were stimulated with an IgE:anti-IgE mixture from day 0 to day 21 , the resulting cells showed a marked suppression of syk expression but were indistinguishable in terms of alcian blue staining, FceRI expression or histamine content [96]. The suppression of syk was bimodal, with approximately $50 \%$ of the cells showing syk 


\section{CD34 progenitor}

\section{Early basophil}

Day 21-derived Basophil

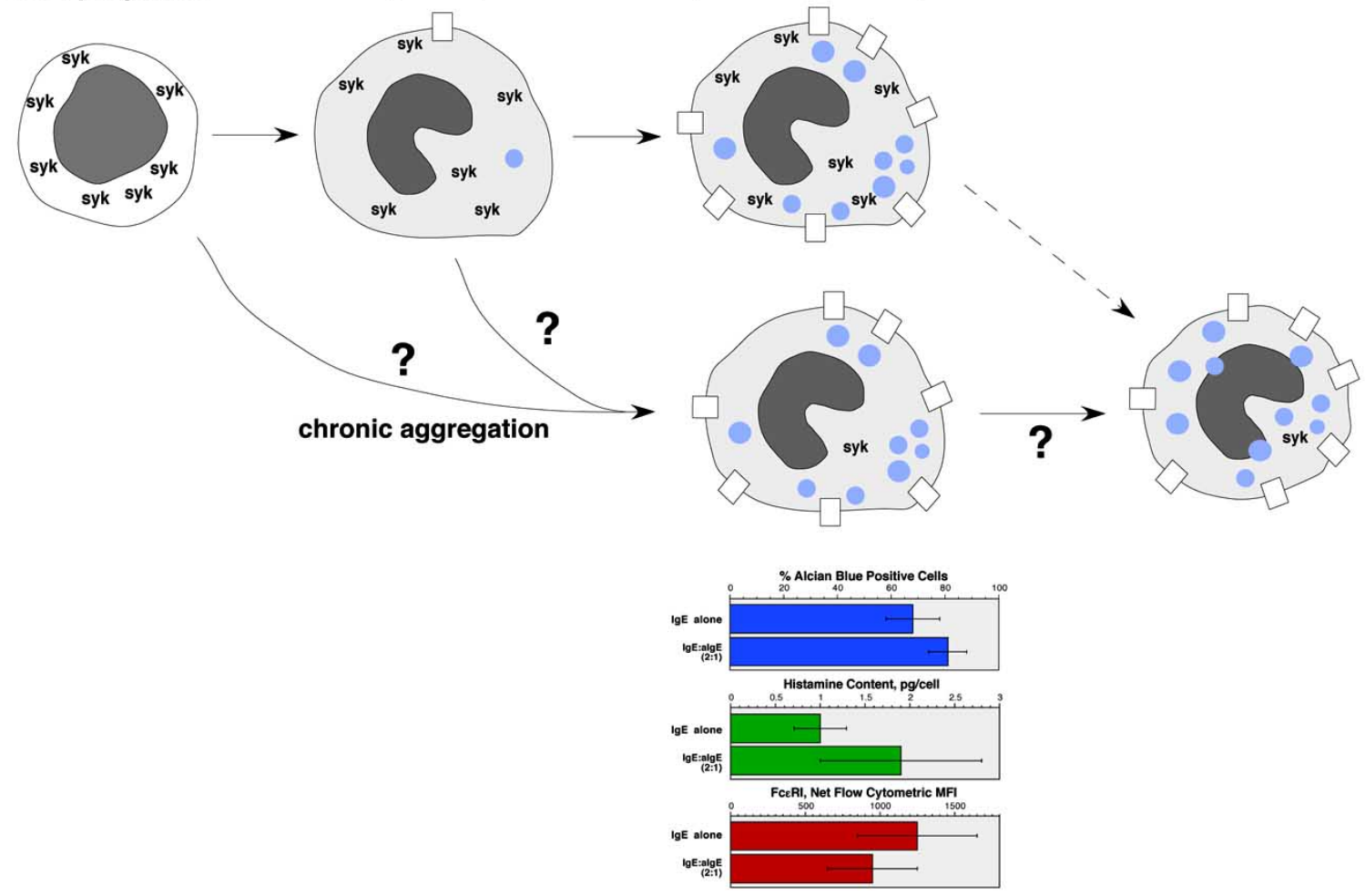

Fig. (4). A hypothesized process that leads from the high levels of syk expression in CD34+ progenitor cells to low levels in mature peripheral blood basophils. The change is hypothesized to involve chronic aggregation (see text). The arrows emanating from the two left-most cells reflect the ambiguity is knowledge about when aggregation exerts an influence of syk expression. Below the day 21 culture-derived basophils are three plots showing the experimental effect on chronic aggregation (an anti-IgE: IgE mixture) on levels of histamine, FceRI expression and alcian blue staining relative to cultures incubated with IgE alone.

levels similar to peripheral blood basophils. The cultures were asynchronously generating basophils and the timing of the down-regulation suggested that relatively immature basophils did not down-regulate syk; this machinery possibly required a somewhat more mature basophil. The general conclusion of this study was that non-stimulated basophils do not down-regulate syk expression and that chronic stimulation does result in syk down-regulation and a cell that is otherwise phenotypically similar to cells not subjected to chronic stimulation (Fig. 4 summarizes the conclusions of this study).

These studies also made note of the fact that the level of mRNA in a day 21 CD34-derived basophil was about 1.5 fold greater than a peripheral blood basophil. However, these cells were cultured in IL-3 and if peripheral blood basophils are cultured in IL-3, their syk mRNA levels are actually more similar to the progenitors since IL-3 results in about a 4 fold greater level of syk mRNA. If there is so much syk mRNA available in an IL-3 treated peripheral blood basophil, why isn't syk expression more similar to the progenitors? It is possible that the steady state of syk expression is perturbed by either a change in constitutive synthesis or constitutive degradation. Youssef et al. proposed that syk in human basophils is rapidly degraded because incubation of the cells with proteasomal inhibitors rapidly and markedly increased syk expression (although, based on the published changes, not to levels observed in other leukocytes) [119]. We were unable to find this effect with proteasomal inhibi- tors (although we did note that these inhibitors altered the presence of ubiquinated species of syk following $\operatorname{IgE}$ mediated stimulation) and also found that incubation cycloheximide did not alter the expression of syk [111]. If syk could be up-regulated so quickly by blunting degradation, the implication is that synthesis is fast and possibly similar to other leukocytes (or CD34 day 21-derived basophils). Therefore, the absence of an effect of cycloheximide suggests that synthesis is not rapid. To follow this chain of logic, our own data suggest the hypothesis that translation of the available syk mRNA is curtailed in mature basophils. Unpublished metabolic labeling studies do indeed suggest that syk is poorly synthesized in mature cells. If so, then these experiments suggest that there is either specific or global suppression of syk synthesis in a mature cell and this possibility leads to the many possible ways that mRNA translation can be controlled, e.g., miRNA regulation. But further work is needed to clarify the processes that are operative.

The studies of syk expression in chronically stimulated CD34-derived basophils suggested that in normal individuals, there is some level of chronic stimulation by a ligand that requires syk activation. In atopic subjects, it is possible that antigen circulates and provides an IgE-Ag-mediated stimulation of maturing basophils. But this possibility doesn't explain the similarly low levels of syk expression in basophils in non-atopic subjects. However, one proposal has been that circulating anti-IgE or anti-FceRI antibodies could 
influence syk expression in developing basophils. As noted above, these antibodies were first thought to be pathological and causative agents in chronic idiopathic urticaria but subsequent studies have shown that they are present in nonatopic subjects without evidence of any disease. The level of syk expression is highly variable and it may be that this variability is a reflection of the highly variable presence of anti$\mathrm{IgE}$ or anti-FceRI antibodies with aggregating potential. This has yet to be determined but in the interim, a related experiment was performed. Treatment of patients with omalizumab (non-aggregating anti-IgE antibody) results in marked suppression of circulating free $\mathrm{IgE}$ and a concomitant suppression of FceRI density on basophils and mast cells. Therefore, if chronic stimulation through either IgE or FceRI is normally active in patients (by whatever IgE-mediated mechanism, circulating antigen or anti-IgE/FceRI antibodies), this level of chronic stimulation would be suppressed in patients treated with omalizumab. Based on the CD34 studies, the prediction would be an increase in syk expression. This prediction is counter-intuitive because it is known that treatment with omalizumab reduces antigen-induced histamine release in human basophils. Furthermore, one might expect, although it has not been formally demonstrated, that the cytokine environment in these patients would be shifted away from a Th2-like state. In other words, it is not unreasonable to expect that there would be less IL-3 (or similarly acting cytokines) present. The results of this experiment did follow the prediction based on the CD34 studies, syk expression levels in circulating basophils increased 1.5 to 2 fold [24]. In concert, histamine release induced by anti-IgE antibody also increased 1.5-2 fold. It should be noted that antigen-induced release was suppressed, as previously shown, but this is likely the consequence of the marked suppression in $\operatorname{IgE}$ and FceRI expression. But these studies noted that while both cell surface IgE and FceRI were suppressed in this study, the level of suppression still produced a cell with more than enough IgE/cell to initiate a robust response provided all of it were crosslinked (a condition satisfied by the stimulation with anti-IgE antibody in vitro). While syk levels increased in the basophils, the expression of c-cbl did not. In addition, there was no change in histamine content, no change in the response to FMLP and a decrease in the ratio of FcR $\beta$ :FceRI $\alpha$. Previous studies have noted that the expression of FcR $\beta$ is sensitive to the presence of IL-3 and a reduction in the relative presence of $F c R \beta$ could be interpreted as a decrease in the presence of IL-3 (or a cytokine with similar influence) in the environment of the basophil. Even if this interpretation is stretching the observation too far, the combination of the various observations about c-cbl expression, the FMLP response and FcR $\beta$ expression do not point to an environment of increased IL-3, which might also increase syk expression.

This study also noted that there were no statistically significant changes in syk expression in dendritic cells, providing some support for the effect being selective for basophils. In addition, the degree of up-regulation was a strict function of the starting level of syk expression. An extrapolation of this relationship predicted that the optimal level of syk expression could be about 1/5 of a CD34-derived basophil. This level is very similar to the level of syk expression in human lung mast cells. Taken together with a variety of evi- dence, these results led to the proposal that a developing basophil naturally suppresses syk expression about 5 fold and that in the presence of chronic stimulation can eliminate the remaining expression. In other words, there is a transcriptional component to maturation and a post-translational component. This proposal necessarily claims that in vitro generation of basophils from CD34 progenitors (without chronic aggregation) does not generate a cell with the full phenotype of peripheral blood basophil, i.e., at least one mechanism would not be operative, the $80 \%$ reduction in syk expression.

\section{ASSOCIATIONS WITH OTHER SIGNALING SPE- CIES}

In the sections above, a very specific set of hypotheses regarding IgE-mediated secretion and the involvement of syk expression were explored. But the phenotype of basophils found in patients with various atopic conditions does not necessarily follow this chain of logic. For example, in patients with chronic idiopathic urticaria, the level of syk expression does not track well with the responsiveness of the basophils [87, 120] although there are exceptions. Likewise, in cells that are sensitive to stimulation with HRF, syk expression levels are not explanatory [121]. In these conditions, the level of SHIP expression is a better predictor of the basophil response. SHIP is a phosphatase that specifically metabolizes phosphatidyl-3,4,5 inositol phospholipids (PIP3) to their PIP2 form, removing an important recruitment lipid from the membrane and reducing cellular responses in the process. SHIP is recruited to the membrane in human basophils during stimulation and the kinetics of signaling cascades that are dependent on the presence of PIP3 are consistent with this recruitment [122, 123]. No formal demonstration that SHIP modulates these pathways has been made in human basophils but studies in other cell models [124, 125] support this perspective. For basophils sensitive to stimulation with HRF, SHIP expression levels are lower than found in the general population [121]. Indeed, it is remarkable that a survey of the general population does not really observe levels as low as found in basophils from this kind of subject. The kinetics of the PIP3 dependent signaling step, phosphorylation of Akt, is consistent with the relative absence of SHIP, i.e., phospho-Akt signaling is relatively sustained [123]. In contrast, basophils of CIU patients that show suppressed IgE-mediated response show higher levels of SHIP, although the better predictor was the level of SHIP2 [120], a variant of SHIP that has not been well studied in human basophils [122]. There are also no studies of SHIP expression regulation to help understand how the phenotypic state of these basophils is achieved.

\section{SIGNATURES: THE GENERAL APPROACH}

The various phenotypes being explored in atopic patients might not be dependent on IgE-mediated signaling. The vast set of receptors that basophils express could provide a means to generate basophils with different circulating phenotypes. One possible way that this problem could be approached is by not proposing a specific hypothesis but by exploring the state of the basophil, searching for a "signature" of disease phenotype. This has only recently been attempted because basophils are generally not available in quantities sufficient 
for the various screening methods. For example, proteomics is out the question, requiring tens to hundreds of millions of cells for a deep exploration of the proteome (i.e., to characterize the less well expressed proteins, which usually includes all the interesting signaling proteins). In recent years, transcriptosome microarrays have become sensitive enough to perform selected surveys. For example, Youseff et al. explored the phenotype of basophils stimulated with anti-IgE for short periods and examined the resting (and stimulated) signature of non-releasing basophils [76]. These studies were interesting for the relatively modest changes induced in basophils with anti-IgE antibody and the very subtle differences between the non-releasing and releasing phenotypes. Our own microarray results for short periods of stimulation are qualitatively similar with a few exceptions regarding which transcripts are increased (e.g., we don't observe changes in the subunits of FceRI). But most notable in the entire data set, at least relative to changes observed with other methods of stimulation) are the very modest changes. For example, there were only 13 transcripts that changed greater than the Bonferroni-corrected thresholds established for these particular arrays. The results from the Youssef study on non-releasers was also notable for very little observed differences in transcripts for a wide variety of signaling species. This is consistent with the protein survey where the population distribution of expression for all but syk were statistically identical (within the expected error for the Western blotting technique) [100, 104]. The results of the Youssef survey were a first step in profiling basophils and have not yet progressed to evaluation of basophils from patient phenotypes. Such a study is currently underway.

\section{SUMMARY}

While there is considerably more known about signaling in human basophils, there are many unexplored pathways. Nevertheless, some of this research has already provided some tantalizing clues into the origins of basophil phenotypes that may have relevance to understanding atopic diseases. Recent studies have also pointed towards the need to understand more about the developmental pathways of basophils and how modulation of signal element expression during maturation may impinge on the cells that are routinely studied from peripheral blood. In some of these studies, there are indications that the circulating basophil may act as a sensor of events that might occur during its maturation.

\section{REFERENCES}

[1] Kitamura Y, Shimada M, Hatanaka K, Miyano Y. Development of mast cells from grafted bone marrow cells in irradiated mice. Nature 1977; 268: 442-4.

[2] Fukuzumi T, Waki N, Kanakura Y, et al. Differences in irradiation susceptibility and turnover between mucosal and connective tissuetype mast cell of mice. Exp Hematol 1990; 18: 843-50.

[3] Kiernan JA. Production and lifespan of cutaneous mast cells in young rats. J Anat 1979; 128: 255-62.

[4] Gurish MF, Boyce JA. Mast cell growth, differentiation, and death. Clin Rev Allergy Immunol 2002; 22: 107-25.

[5] Arndt D, Parwaresch MR. Kinetics of human basophilic granulocytes. Folia Haematol Int Mag Klin Morphol Blutforsch 1977; 104: 24-36.

[6] Parwaresch MR, Nottbohm F. Quantitation of basophil cell-line in human bone marrow (author's transl). Klin Wochenschr 1975 ;53: 661-71.

[7] Irani AA, Huang C, Zweiman B, Schwartz LB. Immunohistochemical detection of basophil infiltration in the skin during the IgE-mediated late phase reaction. J All Clin Immunol 1997; 99: S92.

[8] Irani AM, Huang C, Xia HZ, et al. Immunohistochemical detection of human basophils in late-phase skin reactions. J Allergy Clin Immunol 1998; 101(3): 354-62.

[9] von Allmen C, Zweiman B, Irani AM, Baron M, Schwartz LB. Temporal pattern of basophil accumulation in cutaneous late-phase reactions. J Allergy Clin Immunol 2000; 105(1): S61.

[10] Creticos PS, Adkinson NFJ, Kagey SA, et al. Nasal challenge with ragweed pollen in hay fever patients. Effect of immunotherapy [published erratum appears in J Clin Invest 1986; 78(5): 1421]. J Clin Invest 1985; 76(6): 2247-53.

[11] Naclerio RM, Proud D, Togias AG, et al. Inflammatory mediators in late antigen-induced rhinitis. N Engl J Med 1985; 313(2): 65-70.

[12] Naclerio RM, Kagey SA, Lichtenstein LM, et al. Observations on nasal late phase reactions. Immunol Invest 1987; 16(8): 649-85.

[13] Bascom R, Pipkorn U, Lichtenstein LM, Naclerio RM. The influx of inflammatory cells into nasal washings during the late response to antigen challenge: effect of systemic steroid pretreatment. Am Rev Respir Dis 1988; 138: 406-12.

[14] Bascom R, Wachs M, Naclerio RM, Pipkorn U, Galli SJ, Lichtenstein LM. Basophil influx occurs after nasal antigen challenge: effects of topical corticosteroid pretreatment. J Allergy Clin Immunol 1988; 81(3): 580-9.

[15] Iliopoulos O, Baroody F, Naclerio RM, Bochner BS, KageySobotka A, Lichtenstein LM. Histamine containing cells obtained from the nose hours after antigen challenge have functions and phenotypic characteristics of basophils. J Immunol 1992; 148: 2223-8.

[16] Kepley CL, Craig SS, Schwartz LB. Identification and partial characterization of a unique marker for human basophils. J Immunol 1995; 154(12): 6548-55.

[17] Macfarlane AJ, Kon OM, Smith SJ, et al. Basophils, eosinophils, and mast cells in atopic and nonatopic asthma and in late-phase allergic reactions in the lung and skin. J Allergy Clin Immunol 2000; 105(1 Pt 1): 99-107.

[18] Charlesworth EN, Iliopoulos O, MacDonald SM, Kagey SA, Lichtenstein LM. Cells and secretagogues involved in the human late-phase response. Int Arch Allergy Appl Immunol 1989; 88(12): 50-3.

[19] Eckman JA, Sterba PM, Kelly D, et al. Effects of omalizumab on basophil and mast cell responses using an intranasal cat allergen challenge. J Allergy Clin Immunol 2010; 125(4): 889-95 e7.

[20] MacGlashan DW, Jr, Bochner BS, Adelman DC, et al. Downregulation of FceRI expression on human basophils during in vivo treatment of atopic patients with anti-IgE antibody. J Immunol 1997; 158: 1438-45.

[21] MacGlashan DW, Jr., Xia HZ, Schwartz LB, Gong JP. IgEregulated expression of FceRI in human basophils: Control by regulated loss rather than regulated synthesis. J Leuk Biol 2001; 70: 207-18.

[22] Gomez G, Jogie-Brahim S, Shima M, Schwartz LB. Omalizumab reverses the phenotypic and functional effects of IgE-enhanced Fc epsilonRI on human skin mast cells. J Immunol 2007; 179(2):135361.

[23] MacGlashan D. Loss of receptors and $\operatorname{IgE}$ in vivo during treatment with anti-IgE antibody. J Allergy Clin Immunol 2004; 114(6): $1472-4$.

[24] Zaidi AK, Saini SS, Macglashan DW, Jr. Regulation of Syk kinase and FcRbeta expression in human basophils during treatment with omalizumab. J Allergy Clin Immunol 2010; 125(4): 902-8 e7.

[25] Fukuda T, Dunnette SL, Reed CE, Ackerman SJ, Peters MS, Gleich GJ. Increased numbers of hypodense eosinophils in the blood of patients with bronchial asthma. Am Rev Respir Dis 1985; 132(5): 981-5.

[26] Frick WE, Sedgwick JB, Busse WW. Hypodense eosinophils in allergic rhinitis. J Allergy Clin Immunol 1988; 82(1): 119-25.

[27] Chihara J, Nakajima S. Induction of hypodense eosinophils and nuclear hypersegmentation of eosinophils by various chemotactic factors and lymphokines in vitro. Allergy Proc 1989; 10(1): 27-32.

[28] Kloprogge E, de Leeuw AJ, de Monchy JG, Kauffman HF. Hypodense eosinophilic granulocytes in normal individuals and patients with asthma: generation of hypodense cell populations in vitro. J Allergy Clin Immunol 1989; 83(2 Pt 1): 393-400. 
[29] Leonard EJ. Two populations of human blood basophils: effect of prednisone on circulating numbers. J Allergy Clin Immunol 1987; 79(5): 775-80.

[30] May CD. High spontaneous release of histamine in vitro from leukocytes of persons hypersensitive to food. J Allergy Clin Immunol 1976; 58(3): 432-7.

[31] Findlay SR, Lichtenstein LM. Basophil "releasability" in patients with asthma. Am Rev Respir Dis 1980; 122(1): 53-9.

[32] May CD, Remigio L. Observations on high spontaneous release of histamine from leucocytes in vitro. Clin Allergy 1982; 12(3): 22941.

[33] Sampson HA, Broadbent KR, Bernhisel-Broadbent J. Spontaneous release of histamine from basophils and histamine-releasing factor in patients with atopic dermatitis and food hypersensitivity. N Engl J Med 1989; 321(4): 228-32.

[34] James JM, Kagey-Sobotka A, Sampson HA. Patients with severe atopic dermatitis have activated circulating basophils. J Allergy Clin Immunol 1993; 91(6): 1155-62.

[35] MacGlashan DW, Jr., Peters SP, Warner J, Lichtenstein LM. Characteristics of human basophil sulfidopeptide leukotriene release: releasability defined as the ability of the basophil to respond to dimeric cross-links. J Immunol 1986; 136(6): 2231-9.

[36] Warner JA, Freeland HS, MacGlashan DW, Jr., Lichtenstein LM, Peters SP. Purified human basophils do not generate LTB4. Biochem Pharmacol 1987; 36(19): 3195-9.

[37] Warner JA, Peters SP, Lichtenstein LM, et al. Differential release of mediators from human basophils: differences in arachidonic acid metabolism following activation by unrelated stimuli. J Leukoc Biol 1989; 45(6): 558-71.

[38] MacGlashan DW, Jr., White JM, Huang SK, Ono SJ, Schroeder J, Lichtenstein LM. Secretion of interleukin-4 from human basophils: The relationship between IL-4 mRNA and protein in resting and stimulated basophils. J Immunol 1994; 152: 3006-16.

[39] Ochensberger B, Daepp GC, Rihs S, Dahinden CA. Human blood basophils produce interleukin-13 in response to IgE-receptordependent and -independent activation. Blood 1996; 88: 3028-32.

[40] Li H, Sim TC, Alam R. IL-13 released by and localized in human basophils. J Immunol 1996; 156(12): 4833-8.

[41] Schroeder JT, Chichester KL, Bieneman AP. Human basophils secrete IL-3: evidence of autocrine priming for phenotypic and functional responses in allergic disease. J Immunol 2009; 182(4): 2432-8.

[42] Li H, Sim TC, Grant JA, Alam R. The production of macrophage inflammatory protein-1 alpha by human basophils. J Immunol 1996; 157(3): 1207-12.

[43] de Paulis A, Prevete N, Fiorentino I, et al. Expression and functions of the vascular endothelial growth factors and their receptors in human basophils. J Immunol 2006; 177(10): 7322-31.

[44] Bochner BS, Peachell PT, Brown KE, Schleimer RP. Adherence of human basophils to cultured umbilical vein vascular endothelial cells. J Clin Invest 1988; 81: 1355-60.

[45] Tschopp CM, Spiegl N, Didichenko S, et al. Granzyme B, a novel mediator of allergic inflammation: its induction and release in blood basophils and human asthma. Blood 2006; 108(7): 2290-9.

[46] de Weck AL, Sanz ML, Gamboa PM, et al. Diagnostic tests based on human basophils: more potentials and perspectives than pitfalls. Int Arch Allergy Immunol 2008; 146(3): 177-89.

[47] Sudheer PS, Hall JE, Read GF, Rowbottom AW, Williams PE. Flow cytometric investigation of peri-anaesthetic anaphylaxis using CD63 and CD203c. Anaesthesia. 2005; 60(3): 251-6.

[48] Sonneck K, Baumgartner C, Rebuzzi L, et al. Recombinant allergens promote expression of aminopeptidase-n (CD13) on basophils in allergic patients. Int J Immunopathol Pharmacol 2008; 21(1): 11-21.

[49] Hennersdorf F, Florian S, Jakob A, et al. Identification of CD13, CD107a, and CD164 as novel basophil-activation markers and dissection of two response patterns in time kinetics of $\mathrm{IgE}$ dependent upregulation. Cell Res 2005; 15(5): 325-35.

[50] Aerts NE, Dombrecht EJ, Bridts $\mathrm{CH}$, et al. Simultaneous flow cytometric detection of basophil activation marker CD63 and intracellular phosphorylated p38 mitogen-activated protein kinase in birch pollen allergy. Cytometry B Clin Cytom 2008; 76B(1): 817.

[51] Apostolou E, Deckert K, Puy R, et al. Anaphylaxis to Gelofusine confirmed by in vitro basophil activation test: a case series. Anaesthesia 2006; 61(3): 264-8.
[52] Lourenco FD, Azor MH, Santos JC, et al. Activated status of basophils in chronic urticaria leads to interleukin-3 hyperresponsiveness and enhancement of histamine release induced by anti-IgE stimulus. Br J Dermatol 2008; 158(5): 979-86.

[53] Chirumbolo S, Vella A, Ortolani R, et al. Differential response of human basophil activation markers: a multi-parameter flow cytometry approach. Clin Mol Allergy 2008; 6: 12-25.

[54] Nagao M, Hiraguchi Y, Hosoki K, et al. Allergen-induced basophil CD203c expression as a biomarker for rush immunotherapy in patients with Japanese cedar pollinosis. Int Arch Allergy Immunol 2008; 146 Suppl 1: 47-53.

[55] Buhring HJ, Streble A, Valent P. The basophil-specific ectoenzyme E-NPP3 (CD203c) as a marker for cell activation and allergy diagnosis. Int Arch Allergy Immunol 2004; 133(4): 317-29.

[56] Boumiza R, Debard AL, Monneret G. The basophil activation test by flow cytometry: recent developments in clinical studies, standardization and emerging perspectives. Clin Mol Allergy 2005; 3: 9-16.

[57] Knol EF, Mul FPJ, Jansen H, Calafat J, Roos D. Monitoring human basophil activation via CD63 monoclonal antibody 435. J All Clin Immunol 1991; 88: 328-38.

[58] Furuno T, Teshima R, Kitani S, Sawada J, Nakanishi M. Surface expression of CD63 antigen (AD1 antigen) in P815 mastocytoma cells by transfected IgE receptors. Biochem Biophys Res Commun 1996; 219(3): 740-4.

[59] Amano T, Furuno T, Hirashima N, Ohyama N, Nakanishi M. Dynamics of intracellular granules with CD63-GFP in rat basophilic leukemia cells. J Biochem 2001; 129(5): 739-44.

[60] MacGlashan DW, Jr. Expression of CD203c and CD63 in Human Basophils: Relationship to Differential Regulation of Piecemeal and Anaphylactic Degranulation Processes. Clin Exp Allergy [in press].

[61] Dvorak AM, Warner JA, Kissell S, Lichtenstein LM, MacGlashan DW, Jr. F-met peptide-induced degranulation of human basophils. Lab Invest 1991; 64(2): 234-53.

[62] Dvorak AM. Basophils and mast cells: Piecemeal degranulation in situ and ex vivo: A possible mechanism for cytokine-induced function in disease. In: Coffey RG, editor. Granulocyte Responses to Cytokines. New York: Marcel Dekker; 1992. p. 169-271.

[63] Dvorak AM, Warner JA, Morgan E, Kissell-Rainville S, Lichtenstein LM, MacGlashan DW, Jr. An ultrastructural analysis of tumor-promoting phorbol diester-induced degranulation in human basophils. Am J Pathology 1992; 141: 1309-22.

[64] Dvorak AM, Morgan ES, Lichtenstein LM, MacGlashan DW, Jr. Activated Human Basophils Contain Histamine in Cytoplasmic Vesicles. Int Arch Allergy Immunol 1994; 105: 8-11.

[65] Dvorak AM, MacGlashan DW, Jr., Morgan ES, Lichtenstein LM. Vesicular transport of histamine in stimulated human basophils. Blood 1996; 88: 4090-101

[66] Dahinden CA, Geiser T, Brunner T, et al. Monocyte chemotactic protein 3 is a most effective basophil- and eosinophil-activating chemokine. J Exp Med 1994; 179(2): 751-6.

[67] Miura K, MacGlashan DW, Jr. Dual phase priming by interleukin-3 for leukotriene C4 generation in human basophils. J Immunol 2000 164: 3026-34.

[68] Miura K, Hubbard WC, MacGlashan DW, Jr. Phosphorylation of cytosolic PLA2 (cPLA2) by Interleukin-3 (IL-3) is associated with increased free arachidonic acid and LTC4 release in human basophils. J Allergy Clin Immunol 1998; 102: 512-20.

[69] Krieger $M$, von TV, Dahinden CA. Signal transduction for interleukin-3-dependent leukotriene synthesis in normal human basophils: opposing role of tyrosine kinase and protein kinase. Eur J Immunol 1992; 22(11): 2907-13.

[70] Kurimoto Y, de Weck AL, Dahinden CA. The effect of interleukin 3 upon IgE-dependent and IgE-independent basophil degranulation and leukotriene generation. Eur J Immunol 1991; 21(2): 361-8.

[71] Kurimoto Y, de Weck AL, Dahinden CA. Interleukin 3-dependent mediator release in basophils triggered by C5a. J Exp Med 1989; 170(2): 467-79.

[72] Busse WW, Swenson CA, Sharpe G, Koschat M. Enhanced basophil histamine release to concanavalin A in allergic rhinitis. J Allergy Clin Immunol 1986; 78: 90-7.

[73] Marone G, Spadaro G, Patella V, Genovese A. The clinical relevance of basophil releasability. J Allergy Clin Immunol 1994; 94(6 Pt 2): 1293-303. 
[74] Casolaro V, Spadaro G, Marone G. Human basophil releasability. VI. Changes in basophil releasability in patients with allergic rhinitis or bronchial asthma. Am Rev Respir Dis 1990; 142: 110811.

[75] Marone G, Giugliano R, Lembo G, Ayala F. Human basophil releasability. II. Changes in basophil releasability in patients with atopic dermatitis. J Invest Dermatol 1986; 87(1): 19-23.

[76] Youssef LA, Schuyler M, Gilmartin L, et al. Histamine release from the basophils of control and asthmatic subjects and a comparison of gene expression between "releaser" and "nonreleaser" basophils. J Immunol 2007; 178(7): 4584-94.

[77] Nguyen KL, Gillis S, MacGlashan DW, Jr. A comparative study of releasing and nonreleasing human basophils: nonreleasing basophils lack an early component of the signal transduction pathway that follows IgE cross-linking. J Allergy Clin Immunol 1990; 85(6): 1020-9.

[78] MacGlashan DW, Jr., Ishmael S, Macdonald SM, Langdon JM, Arm JP, Sloane DE. Induced Loss of Syk in Human Basophils by Non-IgE-Dependent Stimuli. J Immunol 2008; 180(6): 4208-17.

[79] MacDonald SM, Lichtenstein LM, Proud D, et al. Studies of IgEdependent histamine releasing factors: heterogeneity of IgE. J Immunol 1987; 139(2): 506-12.

[80] Pasmans SG, Aalbers M, Daha MR, Knol EF, Jansen HM, Aalberse RC. Histamine-releasing activity in supernatants of mononuclear cells: contribution of monocyte chemotactic protein-1 activity compared with IgE-dependent activity. J Allergy Clin Immunol 1996; 98(5 Pt 1): 962-8.

[81] Kuna P, Reddigari SR, Rucinski D, Oppenheim JJ, Kaplan AP. Monocyte chemotactic and activating factor is a potent histaminereleasing factor for human basophils. J Exp Med 1992; 175(2): 489-93.

[82] MacDonald S, Lichtenstein LM. Cloning and expression of histamine releasing factor. Science 1995; 269: 688-90.

[83] Wantke F, MacGlashan DW, Langdon JM, MacDonald SM. The human recombinant histamine releasing factor: functional evidence that it does not bind to the IgE molecule. J Allergy Clin Immunol 1999; 103(4): 642-8.

[84] Kleine-Tebbe J, Sobotka AK, MacGlashan DW, Jr., Lichtenstein LM, MacDonald SM. Lectins do not distinguish between heterogeneous $\operatorname{IgE}$ molecules as defined by differential activity of an IgE-dependent histamine releasing factor. J All Clin Immunol 1996; 98: 181-8.

[85] Xie L, Schroeder JT, Langdon JM, Sora-Scott RS, Kawakami T, MacDonald SM. Human IgE+ and IgE- are not equivalent to mouse highly cytokinergic IgE. J Allergy Clin Immunol 2008; 121(4): 1027-33.

[86] Kern F, Lichtenstein LM. Defective histamine release in chronic urticaria. J Clin Invest 1976; 57(5): 1369-77.

[87] Baker R, Vasagar K, Ohameje N, et al. Basophil histamine release activity and disease severity in chronic idiopathic urticaria. Ann Allergy Asthma Immunol 2008; 100(3): 244-9.

[88] Grattan CE, Francis DM, Hide M, Greaves MW. Detection of circulating histamine releasing autoantibodies with functional properties of anti-IgE in chronic urticaria. Clin Exp Allergy 1991; 21(6): 695-704.

[89] Hide M, Francis DM, Grattan CE, Hakimi J, Kochan JP, Greaves MW. Autoantibodies against the high-affinity $\operatorname{IgE}$ receptor as a cause of histamine release in chronic urticaria. N Engl J Med 1993; 328(22): 1599-604.

[90] Hide M, Francis DM, Grattan CE, Barr RM, Winkelmann RK, Greaves MW. The pathogenesis of chronic idiopathic urticaria: new evidence suggests an auto-immune basis and implications for treatment. Clin Exp Allergy 1994; 24(7): 624-7.

[91] Sabroe RA, Francis DM, Barr RM, Black AK, Greaves MW. AntiFc(episilon)RI auto antibodies and basophil histamine releasability in chronic idiopathic urticaria. J Allergy Clin Immunol 1998; 102(4 Pt 1): 651-8.

[92] Kikuchi Y, Kaplan AP. Mechanisms of autoimmune activation of basophils in chronic urticaria. J Allergy Clin Immunol 2001; 107(6): 1056-62.

[93] Soundararajan S, Kikuchi Y, Joseph K, Kaplan AP. Functional assessment of pathogenic IgG subclasses in chronic autoimmune urticaria. J Allergy Clin Immunol 2005; 115(4): 815-21.

[94] Kaplan AP, Joseph K. Basophil secretion in chronic urticaria: autoantibody-dependent or not? J Allergy Clin Immunol 2007; 120(3): 729-30.
[95] Eckman JA, Hamilton RG, Gober LM, Sterba PM, Saini SS. Basophil Phenotypes in Chronic Idiopathic Urticaria in Relation to Disease Activity and Autoantibodies. J Invest Dermatol 2008; 128 : 1956-63.

[96] Ishmael SS, MacGlashan DW, Jr. Syk expression in peripheral blood leukocytes, CD34+ progenitors, and CD34-derived basophils. J Leukoc Biol 2010; 87(2): 291-300.

[97] Zhang J, Berenstein EH, Evans RL, Siraganian RP. Transfection of Syk protein tyrosine kinase reconstitutes high affinity IgE receptormediated degranulation in a Syk-negative variant of rat basophilic leukemia RBL-2H3 cells. J Exp Med 1996; 184(1): 71-9.

[98] Vilarino N, MacGlashan D, Jr. Transient transfection of human peripheral blood basophils. J Immunol Methods 2005; 296(1-2): 11-8.

[99] MacGlashan DW, Jr., Undem BJ. Inducing an Anergic State in Mast Cells and Basophils without Secretion. J Allergy Clin Immunol 2008; 121(6): 1500-6.

[100] MacGlashan DW, Jr. Relationship Between Syk and SHIP Expression and Secretion from Human Basophils in the General Population. J Allergy Clin Immunol 2007; 119: 626-33.

[101] MacGlashan DW, Jr. Releasability of human basophils: Cellular sensitivity and maximal histamine release are independent variables. J Allergy Clin Immunol 1993; 91: 605-15.

[102] Yuan Y, Mendez R, Sahin A, Dai JL. Hypermethylation leads to silencing of the SYK gene in human breast cancer. Cancer Res 2001; 61(14): 5558-61.

[103] Yuan Y, Liu H, Sahin A, Dai JL. Reactivation of SYK expression by inhibition of DNA methylation suppresses breast cancer cell invasiveness. Int J Cancer 2005; 113(4): 654-9.

[104] Ishmael S, MacGlashan D, Jr. Early signal protein expression profiles in basophils: a population study. J Leukoc Biol 2009; 86(2): 313-25.

[105] Ohmori K, Luo Y, Jia Y, et al. IL-3 induces basophil expansion in vivo by directing granulocyte-monocyte progenitors to differentiate into basophil lineage-restricted progenitors in the bone marrow and by increasing the number of basophil/mast cell progenitors in the spleen. J Immunol 2009; 182(5): 2835-41.

[106] Arinobu Y, Iwasaki H, Gurish MF, et al. Developmental checkpoints of the basophil/mast cell lineages in adult murine hematopoiesis. Proc Natl Acad Sci U S A 2005; 102(50): 1810510.

[107] Lantz CS, Min B, Tsai M, Chatterjea D, Dranoff G, Galli SJ. IL-3 is required for increases in blood basophils in nematode infection in mice and can enhance IgE-dependent IL-4 production by basophils in vitro. Lab Invest 2008; 88(11): 1134-42.

[108] Shen T, Kim S, Do JS, et al. T cell-derived IL-3 plays key role in parasite infection-induced basophil production but is dispensable for in vivo basophil survival. Int Immunol 2008; 20(9): 1201-9.

[109] Vilarino N, Miura K, MacGlashan DW, Jr. Acute IL-3 priming upregulates the stimulus-induced Raf-1-Mek-Erk cascade independently of IL-3-induced activation of Erk. J Immunol 2005; 175(5): 3006-14.

[110] Kepley CL, Youssef L, Andrews RP, Wilson BS, Oliver JM. Multiple defects in Fc epsilon RI signaling in Syk-deficient nonreleaser basophils and IL-3-induced recovery of Syk expression and secretion. J Immunol 2000; 165(10): 5913-20.

[111] MacGlashan D, Miura K. Loss of syk kinase during IgE-mediated stimulation of human basophils. J Allergy Clin Immunol 2004; 114(6): 1317-24.

[112] Ota Y, Beitz LO, Scharenberg AM, Donovan JA, Kinet JP, Samelson LE. Characterization of Cbl tyrosine phosphorylation and a Cbl-Syk complex in RBL-2H3 cells. J Exp Med 1996; 184(5): 1713-23.

[113] Ota Y, Samelson LE. The product of the proto-oncogene c-cbl: a negative regulator of the Syk tyrosine kinase. Science 1997; 276(5311): 418-20.

[114] Paolini R, Molfetta R, Beitz LO, et al. Activation of Syk tyrosine kinase is required for c-Cbl-mediated ubiquitination of Fcepsilon RI and Syk in RBL cells. J Biol Chem 2002; 277(40): 36940-7.

[115] Kepley CL. Antigen-induced reduction in mast cell and basophil functional responses due to reduced Syk protein levels. Int Arch Allergy Immunol 2005; 138(1): 29-39.

[116] MacGlashan DW, Jr. Self-Termination/Anergic Mechanisms in Human Basophils and Mast Cells. Int Arch Allergy Immunol 2009; 150(2): 109-21. 
[117] Kepley CL, Pfeiffer JR, Schwartz LB, Wilson BS, Oliver JM. The identification and characterization of umbilical cord blood-derived human basophils. J Leukoc Biol 1998; 64(4): 474-83.

[118] Langdon JM, Schroeder JT, Vonakis BM, Bieneman AP, Chichester K, Macdonald SM. Histamine-releasing factor/translationally controlled tumor protein (HRF/TCTP)induced histamine release is enhanced with SHIP-1 knockdown in cultured human mast cell and basophil models. J Leukoc Biol 2008; 84(4): 1151-8.

[119] Youssef LA, Wilson BS, Oliver JM. Proteasome-dependent regulation of Syk tyrosine kinase levels in human basophils. J Allergy Clin Immunol 2002; 110(3): 366-73.

[120] Vonakis BM, Saini SS. Syk-deficient basophils from donors with chronic idiopathic urticaria exhibit a spectrum of releasability. J Allergy Clin Immunol 2008; 121(1): 262-4.

[121] Vonakis BM, Gibbons S, Jr., Sora R, Langdon JM, MacDonald SM. Src homology 2 domain-containing inositol 5' phosphatase is negatively associated with histamine release to human recombinant histamine- releasing factor in human basophils. J Allergy Clin Immunol 2001; 108(5): 822-31.
[122] MacGlashan DW, Jr., Vilarino N. Nonspecific Desensitization, Functional Memory and the Characteristics of SHIP Phosphorylation Following IgE-Mediated Stimulation of Human Basophils. J Immunol 2006; 177: 1040-51.

[123] Vonakis BM, MacGlashan DW, Jr., Vilarino N, Langdon JM, Scott RS, MacDonald SM. Distinct Characteristics of Signal Transduction Events by Histamine Releasing Factor/Translationally Controlled Tumor Protein (HRF/TCTP)Induced Priming and Activation of Human Basophils. Blood 2008; 111: 1789-96.

[124] Huber M, Helgason CD, Damen JE, Liu L, Humphries RK, Krystal G. The src homology 2-containing inositol phosphatase (SHIP) is the gatekeeper of mast cell degranulation. Proc Natl Acad Sci USA 1998; 95(19): 11330-5.

[125] Rauh MJ, Kalesnikoff J, Hughes M, Sly L, Lam V, Krystal G. Role of Src homology 2-containing-inositol 5'-phosphatase (SHIP) in mast cells and macrophages. Biochem Soc Trans 2003; 31(Pt 1): 286-91.

(C) Donald MacGlashan; Licensee Bentham Open.

This is an open access article licensed under the terms of the Creative Commons Attribution Non-Commercial License (http://creativecommons.org/licenses/by-nc/3.0/) which permits unrestricted, non-commercial use, distribution and reproduction in any medium, provided the work is properly cited. 